\title{
HOUSEHOLD CONSUMPTION EXPENDITURES IN TURKEY: A COMPARATIVE QUANTILE REGRESSION ANALYSIS
}

\author{
TÜRKİYE'DE HANEHALKI TÜKETIMM HARCAMALARI ÜZERİNE \\ KARŞILAŞTIRMALI BİR KANTİL REGRESYON ANALIZİ
}

\author{
Gizem ACET DÖNMEZ* \\ Hurşit GÜNEŞ** iD
}

\begin{abstract}
Consumption is one of the key concepts in economics due to its animate connections with GDP, savings, and utility. The current study aims to analyse the relationship between household consumption expenditures and some household characteristics in Turkey through Household Budget Surveys of TurkStat for the years 2002 and 2018. With the implementation of quantile regression estimations, it is shown that disposable income emerges as a very important determinant of consumption expenditures as suggested by the conventional theories of consumption. Most of the households, who intensify their savings, especially to purchase real estate, reduce their consumption levels. It is also observed that the household-heads who are single or enjoy a higher level of education spend more. Although the age of the household head is positively associated with the level of consumption in 2002, this relationship seems to be reversed in 2018 . Regarding economic growth trends in the Turkish economy, such an observation might support the lifecycle theory. The households who use credit cards and online shopping are associated with a higher level of consumption expenditure compared to those who do not use these opportunities.

Keywords: Consumer Economics: Empirical Analysis, Quantile Regressions, Household Consumption JEL Classification: D12, C31

Öz

Tüketim özellikle GSYH, tasarruflar ve fayda teorisi ile ilişkileri nedeniyle iktisat alanında çok önemli bir yere sahiptir. Bu çalışmanın amacı hanehalkı tüketim harcamaları ile bazı hanehalkı özellikleri arasındaki ilişkiyi analiz etmektir. Bu amaçla, TÜİK’in 2002 ve 2018 yıllarındaki Hanehalkı Bütçe Anketleri kullanılmıştır. Kantil regresyon tahminleri, kullanılabilir gelirin geleneksel tüketim teorilerinin de belirttiği gibi tüketim harcamalarını açıklayan çok önemli bir faktör olduğunu göstermiştir. Genel olarak, daha fazla tasarruf yaparak gayrimenkul satın alan hanelerin daha az tüketim yaptığı gözlenmiştir. Eğitim seviyesi daha yüksek

* Res. Asst., Marmara University, Department of Economics, Istanbul, E-Mail: gizem.acet@marmara.edu.tr, ORCID ID: 0000-0002-3936-7147

** Prof. Dr., Marmara University, Department of Economics, Istanbul, E-Mail: hursit@marmara.edu.tr, ORCID ID: 0000-0003-2441-4171
\end{abstract}


ve bekar hanehalkı reislerinin olduğu hanelerde daha fazla tüketim yapıldığı ortaya çıkmıştır. 2002 yılında hanehalkı reisinin yaşı tüketim harcamaları ile pozitif yönlü bir ilişkiye sahip iken, 2018 yılında bu ilişki tersine dönmüştür. Türkiye ekonomisindeki büyüme trendleri göz önünde bulundurulduğunda bu bulgu yaşam boyu gelir teorisini destekler niteliktedir. Kredi kartı kullanan ve online alışveriş yapan hanelerin bu olanakları kullanmayan hanelere göre daha fazla tüketim harcaması yaptığı sonucuna ulaşılmıştır. Kredi kartları ile e-ticaretin yaygınlaşmasının önemli bir kolaylık sağlaması dolayısıyla bireylerin tüketimini arttırdığı açıktır.

Anahtar Kelimeler: Tüketici Ekonomisi: Ampirik Analiz, Kantil Regresyon, Hanehalkı Tüketimi JEL Sinıflandirması: D12, C31

\section{Introduction}

The role of consumption expenditure in economics can be comprehended by its share within Gross Domestic Product (GDP); 55.8 per cent of GDP in Turkey was composed of household consumption expenditures in 2018. ${ }^{1}$ While GDP provides tracking of the performance of the whole economy, trends in living standards can be better captured through measures of household-level consumption expenditure or income. ${ }^{2}$

According to the utility theory, a higher level of consumption is preferred by consumers because of the assumption of "more is better". A person who consumes more is regarded as having a higher level of economic well-being, as long as a commodity has a positive utility. Therefore, consumption is mostly used as a welfare indicator. Although household income is another widely used welfare indicator, many studies prefer the concept of consumption to the concept of income. For example, an analysis conducted by the UK Office for National Statistics found that household consumption expenditure has a stronger relationship with individual well-being (i.e., life satisfaction, the feeling of worthiness, and happiness) than household income. ${ }^{3}$ Because of the strong connection between consumption expenditures and human well-being, the information on the structure of consumption and how it changes over time will be a major contribution to the understanding of the formation of the standard of living of the society. ${ }^{4}$

On the other hand, criticism towards excessive consumption or consumerism, also known as minimalism, supports the idea of "less is more" with the suggestion that by owning less, more can be achieved through the non-material aspects of life. According to Veblen's concept of conspicuous consumption, individuals desire to consume goods and services beyond their needs to gain a higher status in society. ${ }^{5}$ Veblen had attributed two main characteristics to consumption goods; serviceability

1 Turkish Statistical Institute (2020). Annual GDP 2019, Press Bulletin, https://data.tuik.gov.tr/Bulten/Index?p=AnnualGross-Domestic-Product-2019-33671, (Accessed on: 07.06.2021)

2 Stiglitz, J. E., Sen, A., Fitoussi, J. P. (2009). Report by the Commission on the Measurement of Economic Performance and Social Progress (CMEPSP), p. 12-18, https://ec.europa.eu/eurostat/documents/8131721/8131772/Stiglitz-SenFitoussi-Commission-report.pdf, (Accessed on 10.06.2021)

3 Lewis, J. (2014). Income, Expenditure and Personal Wellbeing, 2011/12, UK Office for National Statistics.

4 OECD (2013). OECD Framework for Statistics on the Distribution of Household Income, Consumption and Wealth, OECD Publishing, https://read.oecd-ilibrary.org/economics/framework-for-statistics-on-the-distribution-ofhousehold-income-consumption-and-wealth_978.926.4194830-en\#page1, (Accessed on: 15.12.2020) 
and honorific aspects. People may consume luxury goods and services (e. g. luxury cars, expensive vacations, clothes) as a show-off to others. Scott states that conspicuous consumption has surged in our time, more than any other time in history. ${ }^{6}$ He links the recent rise in conspicuous consumption with the prevalence of credit cards. He argues that credit cards enable individuals to purchase luxury items. The rising trend of luxury consumption has also influenced Turkish consumers. ${ }^{7}$ Consumption expenditures in Turkey have increased sharply with the facility of foreign borrowing (negative savings) and the development of the financial system. In recent years, striking expansion in credit card usage has been seen in Turkey. Credit cards provide consumers with some opportunities such as short-term cash credit, the possibility of not carrying cash, instalment payments and late payment advantage. These opportunities enable individuals to consume beyond their permanent income. Another expansion has been seen in online shopping among Turkish consumers. The proliferation of online shopping probably improves consumer welfare because it offers consumers a wider variety of products and lower search costs. Since it also intensifies the competition among firms, it can increase efficiency and social welfare by reducing prices. Nevertheless, the opportunities that credit cards and online shopping offer may result in excessive consumption by triggering individuals to buy more than what they need. It is well known that excessive consumption patterns that exacerbate debt accumulation raises the risk of financial fragility and may end up in financial crises ${ }^{8}$.

In this respect, it is important to understand how households or individuals make their consumption decisions, the characteristics of consumption and how such relations have changed over time. For this purpose, this paper traces the factors affecting household consumption expenditures in Turkey for the years 2002 and 2018. It examines the linkages between household consumption expenditure and some household characteristics including income, wealth, savings, credit card usage, online shopping habits, tobacco usage, alcohol usage, and some demographic features (e. g. education level, age, gender, and marital status of household heads) by using Household Budget Surveys (HBS) conducted by the Turkish Statistical Institute (TurkStat). Comparing the relationship between consumption expenditures and household characteristics in 2002 with that in 2018 would allow us to observe how these connections have changed over time.

Table 1 provides an overview of household consumption in Turkey from 2002 to 2018. It indicates that the number of households in Turkey has considerably increased throughout this period. Similarly, average expenditure per household has sharply increased as well. When the shares of different goods and services in the total consumption expenditure are examined, it is seen that food and nonalcoholic beverages have the largest share in 2002 (26.7 \%), but it has declined to 20.3 per cent in 2018. This fall can be attributed to the improvement in the living standards of the Turkish people as a decline in the share of food and non-alcoholic beverages, which are necessary goods, means an

6 Scott, R. H. (2007). Credit Card Use and Abuse: A Veblenian Analysis, Journal of Economic Issues, 41(2): 567-574.

7 Demirezen, Ö. (2015). The Effect of Loans to Private Consumption Expenditures in Turkey, Planning Expertise Thesis, p. 80. (in Turkish)

8 For example, Koh, W. C., Köse, M. A., Nagle, P. S., Ohnsorge, F. L., Sugawara, N. (2020). Debt and Financial Crises, World Bank Policy Research Working Paper, 9116. 
increase in the consumption of other goods and services. The most striking change is in the share of transportation in GDP with a rise from 8.7 per cent in 2002 to 18.3 per cent in 2018.

Table 1: Distribution of Consumption by Types of Expenditure in Turkey

\begin{tabular}{|llllllllllll|}
\hline & $\mathbf{2 0 0 2}$ & $\mathbf{2 0 0 5}$ & $\mathbf{2 0 1 0}$ & $\mathbf{2 0 1 1}$ & $\mathbf{2 0 1 2}$ & $\mathbf{2 0 1 3}$ & $\mathbf{2 0 1 4}$ & $\mathbf{2 0 1 5}$ & $\mathbf{2 0 1 6}$ & $\mathbf{2 0 1 7}$ & $\mathbf{2 0 1 8}$ \\
\hline Households (million) & $\mathbf{1 6 , 4}$ & 17,5 & $\mathbf{1 8 , 8}$ & $\mathbf{1 9 , 3}$ & 20,1 & 20,5 & 21,4 & 21,8 & 22,3 & 23,0 & 23,6 \\
\hline Avg. expenditure & 611 & 1091 & 1843 & 2120 & 2366 & 2572 & 2848 & 3043 & 3406 & 3816 & 4446 \\
\hline Shares in total expenditures (\%) & & & & & & & & & & \\
\hline Food and beverages & 26.7 & 24.9 & 21.9 & 20.7 & 19.6 & 19.9 & 19.7 & 20.2 & 19.5 & 19.7 & 20.3 \\
\hline Alcoholic bev. \& tob. & 4.06 & 4.1 & 4.5 & 4.1 & 4.2 & 4.2 & 4.2 & 4.2 & 4.4 & 4.5 & 4.0 \\
\hline Clothing & 6.27 & 6.2 & 5.1 & 5.2 & 5.4 & 5.3 & 5.1 & 5.2 & 5.2 & 5.0 & 4.8 \\
\hline Housing and rent & 27.3 & 25.9 & 27.1 & 25.8 & 25.8 & 25.0 & 24.8 & 26.0 & 25.2 & 24.7 & 23.7 \\
\hline Furniture & 7.29 & 6.8 & 6.3 & 6.4 & 6.7 & 6.6 & 6.8 & 6.1 & 6.3 & 6.3 & 6.5 \\
\hline Health & 2.33 & 2.2 & 2.1 & 1.9 & 1.8 & 2.1 & 2.1 & 2.0 & 2.0 & 2.2 & 2.2 \\
\hline Transportation & 8.70 & 12.6 & 15.1 & 17.2 & 17.2 & 17.4 & 17.8 & 17.0 & 18.1 & 18.7 & 18.3 \\
\hline Communication & 4.53 & 4.3 & 4.1 & 4.0 & 3.9 & 4.0 & 3.7 & 3.6 & 3.7 & 3.4 & 3.8 \\
\hline $\begin{array}{l}\text { Entertainment and } \\
\text { culture }\end{array}$ & 2.47 & 2.5 & 2.8 & 2.7 & 3.2 & 3.1 & 3.0 & 2.9 & 2.8 & 2.7 & 2.9 \\
\hline Education & 1.33 & 1.9 & 2.0 & 2.0 & 2.3 & 2.4 & 2.4 & 2.2 & 2.3 & 2.3 & 2.3 \\
\hline Restaurants \& hotels & 4.43 & 4.4 & 5.4 & 5.7 & 5.8 & 5.9 & 6.0 & 6.4 & 6.4 & 6.2 & 6.5 \\
\hline Other & 4.60 & 4.1 & 3.7 & 4.3 & 4.2 & 4.3 & 4.3 & 4.3 & 4.2 & 4.4 & 4.9 \\
\hline
\end{tabular}

Source: TurkStat, Household Budget Surveys

The information given in Table 1 is macro-level data which contains the aggregate or average of all households. However, such an aggregation feature of macro-level data obliterates all specific individual characteristics. ${ }^{10}$ More clearly, average consumption gives no information on how people effectively benefit from available resources in the economy. ${ }^{11}$ For instance, average consumption per capita may remain unchanged whilst its distribution becoming more unequal. It is, therefore, important to look at consumption information for different groups and in this respect, micro-level data facilitates the detection of the differences in consumption patterns amongst various individuals. Household Budget Surveys used in the current study provides micro-level information not only on consumption expenditures but also many other household characteristics. The next section provides a brief literature survey on consumption. Section three introduces the data set used in the study. Empirical specification and the estimation results are given in sections four and five, respectively. The results of our study are discussed in the last section.

\section{Literature}

Conventional theories of consumption endure their relevance and validity in the literature. The well-known absolute income hypothesis of Keynes defines consumption as a function of disposable

9 It refers monthly average expenditure per household in Turkish Liras (TL).

10 Deaton, A. (1992). Understanding Consumption, Clarendon Press, Oxford.

11 Stiglitz, Sen, Fitoussi, 2009, 32-33. 
income ${ }^{12}$. On the other hand, according to the life cycle hypothesis individuals do not make their consumption decisions by the sole consideration of their present income level. ${ }^{13}$ Wealth and expected annual income based on lifetime earnings also determine the consumption expenditure patterns. According to the life cycle hypothesis, lifetime resources - thereby consumption - of young individuals are higher in rapidly growing economies, since consumption does not depend on the current level of income but the entire lifetime earnings. Another approach to consumption is the permanent income hypothesis which separates income into permanent and temporary components and argues that consumption is a function of permanent income. ${ }^{14}$

Amongst the fundamental approaches to consumption, there is also the relative income hypothesis which infers that the utility of an individual depends on the relative magnitude of his/her consumption level in the society rather than its absolute level. ${ }^{15}$ According to this hypothesis, the percentage of income consumed by an individual depends on his/her percentile position within the income distribution. The relative income hypothesis also asserts that individuals tend to increase their consumption expenditures immediately by a rise in income, whilst they resist reducing their consumption when their income level falls. There is also the random walk model of consumption - also called rational expectations permanent income hypothesis - which incorporates the idea of rational expectations into the consumption models and sets up the model in such a way that consumers maximize their utility. ${ }^{16}$ This hypothesis puts forward that if consumers comply with the permanent income hypothesis and have rational expectations, then consumption may only change concerning unexpected policy changes. Therefore, consumption is regarded as a random walk because it is a function of only its previous level and the unexpected shock.

There are, of course, some empirical studies on consumption as well. For example, Tapsin and Hepsag investigated household consumption expenditures in EA-18 countries ${ }^{17}$ at the macro level throughout 2000-2012. ${ }^{18}$ The results of their panel data analysis demonstrated that household consumption expenditures were strongly and positively connected with GDP. A similar study held for the Czech Republic for 1993-2012 found that net disposable income, inflation rate and household saving rate had significant connections with household spending. ${ }^{19}$ Another study using microdata of the United Kingdom concluded that uncertainties in the income level had a negative effect on

12 Keynes, J. M. (1936). The General Theory of Employment, Interest and Money. London: Macmillan.

13 Modigliani, F. and Brumberg, R. (1954). Utility Analysis and the Consumption Function: An Interpretation of Crosssection Data, In the Collective Papers of Franco Modigliani, Volume 6. Cambridge, MA and London: MIT Press.

14 Friedman, M. (1957). A Theory of the Consumption Function. Princeton, NJ: Princeton University Press.

15 Duesenberry, J. S. (1949). Income, Saving and the Theory of Consumer Behaviour. Cambridge: Harvard University Press.

16 Hall, R. (1978). Stochastic Implications of the Life Cycle-Permanent Income Hypothesis: Theory and Evidence, Journal of Political Economy, 86 (6): 971-987.

17 Euro area countries; Austria, Belgium, Cyprus, Estonia, France, Finland, Germany, Italy, Latvia, Luxemburg, Malta, Netherlands, Slovakia, Slovenia, Ireland, Greece, Portugal, and Spain.

18 Tapsin, G., Hepsag, A. (2014). An Analysis of Household Consumption Expenditures in EA-18, European Scientific Journal, 10(16): 1-12.

19 Verter, N., Osakwe, C. (2014). A Time Series Analysis of Macroeconomic Determinants of Household Spending in the Era of Cross-cultural Dynamics: Czech Republic as a Case Study, Procedia Economics and Finance, 12(2014): 733-742. 
consumption expenditures, while household size had a positive effect. ${ }^{20} \mathrm{~A}$ study - conducted through OLS and quantile regression - on the determinants of household consumption expenditures in yamgrowing areas of Ghana and Nigeria found that factors such as education, age, household size, farm size, and main occupation appear to be significant determinants of consumption expenditures. ${ }^{21} \mathrm{Luo}$, Wang, and Zhang investigated the impact of e-commerce on consumption growth at the household level in China. ${ }^{22}$ They utilized online sales data from Alibaba Group, and household consumption data from China Family Panel Studies (CFPS) survey and found that e-commerce development was associated with higher consumption growth. Another study on household consumption in China examined the effect of tobacco spending on household expenditures. ${ }^{23}$ Their results showed that tobacco expenditures crowded out other expenditures such as spending on education, medical care, insurance, and investment in farming.

Regarding the studies on consumption in Turkey, for instance, Akbay and Boz found that not only price and income, but also socio-economic and demographic factors (i.e. household size, education, age and gender of household head) account for food consumption expenditures of the Turkish households in 2003. ${ }^{24}$ Çağlayan and Astar investigated the determinants of household consumption expenditures in Turkey for urban and rural areas separately by using HBS 2009 through quantile regression. ${ }^{25}$ They concluded that household consumption was increasing with income and household size. Households with higher education levels and married household heads were consuming more. By using HBS and Annual Survey of Income and Living Conditions (SILC), Albayrak found that relative income, inequality, and household indebtedness affected household consumption in Turkey. ${ }^{26}$ The same study detected a negative connection between relative income and consumption, even after controlling for absolute income level, and thereby concluded that people were consuming to gain or to keep a social status because of the "keeping up with the Joneses effect". ${ }^{27}$

20 Miles, D. (1997). A Household Level Study of the Determinants of Incomes and Consumption, The Economic Journal, 107: 1-25.

21 Mignouna, D. B., Abdoulaye, T., Alena, A., Manyong, V. M., Dontsop, P. N., Ainembabazi, J, H., Asiedu, R. (2015). A Microeconometric Analysis of Household Consumption Expenditure Determinants in Yam-growing Areas of Nigeria and Ghana, Tropicultura, 33(3): 226-237.

22 Luo, X., Wang, Y., Zhang, X. (2019). E-Commerce Development and Household Consumption Growth in China, World Bank Policy Research Working Paper, No 8810.

23 Wang, H., Sindelar, J., Bush, S. (2006) The Impact of Tobacco Expenditure on Household Consumption Patterns in Rural China, Social Science and Medicine, 62(6): 1414-1426.

24 Akbay, C., Boz, İ. (2007). Household Food Consumption in Turkey, European Review of Agricultural Economics, 34 (2): 209-231.

25 Çağlayan, E., Astar, M. (2012). A Microeconometric Analysis of Household Consumption Expenditure Determinants for Both Rural and Urban Areas in Turkey, American International Journal of Contemporary Research, 2(2): 27-34.

26 Albayrak, Ö. (2020). Household Consumption, Household Indebtedness, and Inequality in Turkey: A Microeconometric Analysis, Levy Economics Institute Working Paper, No: 954.

27 Keeping up with the Joneses is an idiom which refers the individuals' comparison of themselves with their neighbours as a benchmark for social class. The idea is the same with the concept of conspicuous consumption of Veblen. 
Ceritoğlu found a positive relationship between the growth rate of consumption and expected real income changes. ${ }^{28}$ Therefore, the results of that study rejected the strict version of the rational expectations permanent income hypothesis but supported the precautionary saving hypothesis for the case of the Turkish economy. Another finding of that study was that the real expansion of the consumer credits had a more significant effect on the growth of consumption than the real interest rates. In another study, Demirezen concluded that bank loans had significant effects on consumption expenditures in Turkey, and consumer credits were more important than commercial credits in stimulating growth through induced private consumption. ${ }^{29}$ In a study on the effect of credit card usage on household expenditures in Turkey, a long-term relationship between consumption and credit card use was observed by using macro-level quarterly data throughout 2002-2015. ${ }^{30}$

Overall, there are numerous studies in the literature which focus on explaining the factors associated with consumption. This paper attempts to contribute by examining some unprecedented factors at micro levels such as the use of tobacco, alcohol, and especially online shopping and credit cards alongside the familiar connections (e.g., household income, wealth, and savings) for the Turkish economy. Another attempt is the comparison of the factors affecting consumption in 2002 with that in 2018 to see the changes in the consumption behaviour of the households in Turkey over time if any.

\section{Data}

This study utilizes the HBS ${ }^{31}$ of 2002 and 2018 conducted by TurkStat. Surveys include repeated cross-sectional data where a random sample is taken from the population at different points in time. In other words, the survey does not cover the same households in each survey year, so that the data set is not a genuine panel. ${ }^{32}$ This study, therefore, adopts cross-sectional analyses for the beginning (2002) and the end (2018) of the survey years separately, instead of a panel data analysis. ${ }^{33}$ These surveys include information on both household consumption expenditures and many other household characteristic traits as mentioned above. Consumption expenditures in these surveys are classified based on the purpose of individual consumption (COICOP). Detailed information about

28 Ceritoğlu, E. (2013). Household Expectations and Household Consumption Expenditures: The Case of Turkey, Central Bank of the Republic of Turkey Working Paper, No: 13/10.

29 Demirezen, 2015, 132-139.

30 Önder, K. (2018). The Effect of Credit Card Usage on Consumer Behaviour, International Journal of Eurasia Social Sciences, 9(32): 1099-1120.

31 Household Budget Statistics micro data set is not an open access data set. The author got permission from the TurkStat to access this data set. For more information about these surveys, you can see: https://www.tuik.gov.tr/media/microdata/ pdf/hanehalki-butce_YeiTwew.pdf, (Accessed on 10.06.2021)

32 A pseudo panel approach could have been followed, but this study does not adopt that approach because pseudo panels have certain limitations such as information loss and sensitivity of estimations to group design.

33 In fact, first HBS of TurkStat was conducted in 1994. TurkStat has reinstated these surveys in 2002. Nonetheless, due to the methodological differences, the current study did not include the survey of 1994 . The 2002 survey is accepted as the beginning, and the most recent survey, which was published in 2018, is accepted as the comparison period of the consumption behaviour. 
COICOP can be found in Table A.1 in the annexe. The number of households that have participated in these surveys is 9555 and 11818 for 2002 and 2018, respectively. ${ }^{34}$ Since these surveys are populationweighted, estimations based on these surveys are congruent estimates of the entire population. The definitions of the variables are given in Table 2.

Table 2: Definition of the Variables

\begin{tabular}{|l|l|}
\hline Variable & Definition \\
\hline Consumption & Monthly consumption expenditure per adult-equivalent \\
Income & Monthly disposable income per adult-equivalent \\
Wealth & Ownership of detached house, flat, summer residence, field, land, vineyard, greenhouse, shop, hotel \\
Tobacco & Whether there is an individual in the household using tobacco (0: no, 1: yes) \\
Alcohol & Whether there is an individual in the household using alcohol (0: no, 1: yes) \\
Credit card & Whether the household uses a credit card (0: no, 1: yes) \\
Online shopping & Whether the household uses online shopping (0: no, 1: yes) \\
Saving & Whether the household saves or not (0: no, 1: yes) \\
Control variables: & \\
Schooling & Years of schooling completed by the household head \\
Age & Age of the household head \\
Gender & Gender of the household head (0: female, 1: male) \\
Marital status & Marital status of the household head (0: not married, 1: married) \\
\hline
\end{tabular}

The modified OECD equivalence scale ${ }^{35}$ is used for consumption and income variables to be able to compare different-sized households. ${ }^{36}$ The number of real estate ownership is used as a proxy for wealth. Since the value of these real estates is unknown (due to unavailability), their quantities are used as a plausible but not perfect proxy for wealth. ${ }^{37} 2002$ Survey does not comprise information on saving, use of credit card, online shopping, tobacco, and alcohol. Hence, the connection between such factors and consumption expenditures are only examined for the year 2018. Summary statistics of the data set can be found in Table A.2 and Table A.3 in the annexe.

\section{Empirical Specification}

Besides the relationship between consumption expenditure and the characteristics of households, other factors which could potentially influence consumption expenditure are also included in our analysis. Schooling, age, gender, and marital status of household heads are used as control variables for this purpose. The models estimated in the study are as follows.

34 Four households in 2002 survey are dropped from the data set because their income levels are either zero or negative.

35 The modified OECD equivalence scale gives 1 to the first adult in a household; 0.5 for the other members of the household older than 14; and 0.3 for those younger than 14. By summing these numbers adult equivalent scale of the household is determined. Income and consumption expenditures of each household are divided to this scale, so that per adult-equivalent values are found.

36 Equivalence scales allow to consider fixed costs of running a household and the differences in the needs of adults and children.

37 Naturally this data carries the deficiency that each quantity of real estate is not equivalent with the others. Thus, data is assumed to be homogeneous. 
$\log (\text { consumption })_{\mathrm{i}}=\alpha_{0}+\alpha_{1} \log \left(\right.$ income $_{) \mathrm{i}}+\alpha_{2}$ wealth $_{\mathrm{i}}+\gamma \mathrm{X}+\mathrm{u}_{\mathrm{i}}$

$\log (\text { consumption })_{\mathrm{i}}=\beta_{0}+\beta_{1} \log \left(\right.$ income $_{\mathrm{i}}+\beta_{2}$ wealth $_{\mathrm{i}}+\beta_{3}$ saving $_{\mathrm{i}}+\beta_{4}$ creditcard $_{\mathrm{i}}+\beta_{5}$ onlineshopping $_{\mathrm{i}}+$ $\beta_{6}$ tobacco $_{\mathrm{i}}+\beta_{7}$ alcohol $_{\mathrm{i}}+\delta \mathrm{X}+\mathrm{e}_{\mathrm{i}}$

Dependent variables of the models are in the natural logarithm of equivalized household consumption expenditure. The income variable is also used in the natural logarithm to interpret its coefficient as income elasticity. X refers to the matrix of the control variables, as mentioned above. Populationweights have been used to estimate the whole population. The second model is estimated only for the year 2018 because the required data is not available in the 2002 survey. These models are estimated through the quantile regression method. Quantile regression, introduced by Koenker and Basset, is used as an alternative to ordinary least squares (OLS) regression. ${ }^{38}$ While OLS minimizes the sum of squared errors, quantile regression minimizes the sum of the absolute value of errors. It provides full information about the effect of covariates on the entire distribution of the dependent variable. ${ }^{39}$ It has some advantages relative to OLS. For instance, it deals with heteroskedasticity; does not lose the information about tails of the distribution; and is not sensitive to extreme outliers like OLS. In short, quantile regression can give a more comprehensive view of the relationships among variables. Henceforth, quantile regression is superior in tracking the connection between consumption and household characteristics of different consumption groups.

\section{Results}

Before starting empirical analyses, correlations among the variables have been checked. Pairwise correlations can be seen in Table A.4 and Table A.5 in the annexe. According to these results, the "gender" variable is highly correlated with "marital status". Most of the male household heads (more than 70 per cent) were married both in 2002 and 2018 surveys. Therefore, the gender variable has been dropped from the model to prevent possible multicollinearity. Estimation results of the quantile regression based on HBS 2002 can be seen in Table 3. The results of the OLS estimation are also displayed in the table for comparative comprehension. According to these results, a one per cent increase in income entails around a 0.6 per cent increase in consumption expenditures for all quantiles. Wealth has a significant and negative effect on consumption in 2002 except for the highest quantile as such effects weaken with the rise in quantiles. The connection is stronger for the lower quantiles implying that households in these quantiles try to save to own real estate. Nevertheless, OLS estimation does not capture the relation between wealth and consumption at all. Schooling emerges to increase consumption expenditures for all quantiles. One year more educated household head is associated with around one per cent increase in consumption. Age appears to a significant and positive determinant for all quantiles except for the highest one. A household with a one-year older household head spends approximately 0.1 per cent more on consumption. Marital status does not seem to be a significant determinant for the lower quantiles,

38 Koenker, R., Basset, G.W. (1978). Regression Quantile, Econometrica, 46(1): 33-50.

39 John, O. O., Nduka E. C. (2009). Quantile Regression Analysis as A Robust Alternative to Ordinary Least Squares, Scientia Africana, 8(2) 61-65. 
but it is significantly negative for the higher quantiles as married couples in such quantiles spend less. Unlike the conventional/global $\mathrm{R}^{2}$ of OLS, the pseudo $\mathrm{R}^{2}$ of the quantile regression is the local measure of fit since it depends on the quantile. Therefore, it is not so appropriate to compare $\mathrm{R}^{2}$ of OLS with that of quantile regression.

Table 3: Estimation Results of 2002

\begin{tabular}{|c|c|c|c|c|c|}
\hline Variables & OLS & $(0.2)$ & $(0.4)$ & $(0.6)$ & $(0.8)$ \\
\hline \multirow[t]{2}{*}{$\log$ (income) } & $.566^{\star * *}$ & $.570^{\star * \star}$ & $.621^{\star * *}$ & $.622^{\star * *}$ & $.577^{* * *}$ \\
\hline & (37.09) & $(49.28)$ & $(57.36)$ & $(64.65)$ & $(45.80)$ \\
\hline \multirow[t]{2}{*}{ wealth } & -.00471 & $-.0185^{\star * *}$ & $-.0179^{* * *}$ & $-.0124^{*}$ & .00234 \\
\hline & $(0.99)$ & $(3.60)$ & $(3.47)$ & $(2.46)$ & $(0.37)$ \\
\hline \multirow[t]{2}{*}{ schooling } & $.0124^{* * *}$ & $.0131^{* * *}$ & $.0102^{* * *}$ & $.0090^{* * *}$ & $.0099^{* * *}$ \\
\hline & (13.79) & $(16.54)$ & $(12.54)$ & $(12.72)$ & $(9.81)$ \\
\hline \multirow[t]{2}{*}{ age } & $.00094^{\star * *}$ & $.00127^{\star * *}$ & $.00128^{\star * *}$ & $.00095^{* * *}$ & .00047 \\
\hline & $(3.74)$ & $(4.13)$ & $(4.99)$ & $(4.02)$ & $(1.54)$ \\
\hline \multirow[t]{2}{*}{ marital status } & $-.0230^{*}$ & -.0153 & -.0167 & $-.0228^{* *}$ & $-.0336^{\star}$ \\
\hline & $(2.08)$ & $(1.44)$ & $(1.61)$ & $(2.65)$ & $(2.15)$ \\
\hline \multirow[t]{2}{*}{ constant } & $.894^{* * *}$ & $.722^{\star * *}$ & $.714^{* * *}$ & $.819^{* * *}$ & $1.051^{* * *}$ \\
\hline & $(25.38)$ & $(26.19)$ & $(25.96)$ & $(32.58)$ & $(29.56)$ \\
\hline Pseudo $\mathrm{R}^{2}$ & 0.56 & 0.36 & 0.369 & 0.368 & 0.359 \\
\hline
\end{tabular}

Note: $t$ statistics in absolute value are in parentheses. ${ }^{*} \mathrm{p}<0.05,{ }^{* *} \mathrm{p}<0.01,{ }^{* *} \mathrm{p}<0.001$

Graph 1 indicates the confidence intervals of OLS and quantile regression. Horizontal-dashed lines depict the confidence intervals of OLS estimation, while others show those of the quantile regression. Confidence intervals of income, wealth, and schooling based on quantile regression do not coincide with those of OLS. This finding supports the significance of the quantile regression.

Table 4 includes the estimation results based on HBS 2018. Both models introduced in Section four are estimated for all quantiles. Adding new variables into the first model barely change the coefficients of the variables (with some exceptions). According to the results, a 1 per cent increase in income is associated with around a 0.7 per cent increase in consumption expenditures. OLS underestimates the connections between income and consumption for the higher quantiles. Wealth has a negative effect on consumption for lower quantiles, but a positive effect for the higher ones, although its significance may change depending on the choice of model. OLS does not capture these different connections. This finding implies that households at lower quantiles save more to buy real estates, at the expense of consuming less, whereas the higher consumption of households in upper quantiles does not affect their expansion of wealth (i.e., real estate holdings). 
Graph 1: Confidence Intervals of OLS vs. Quantile Regression in 2002
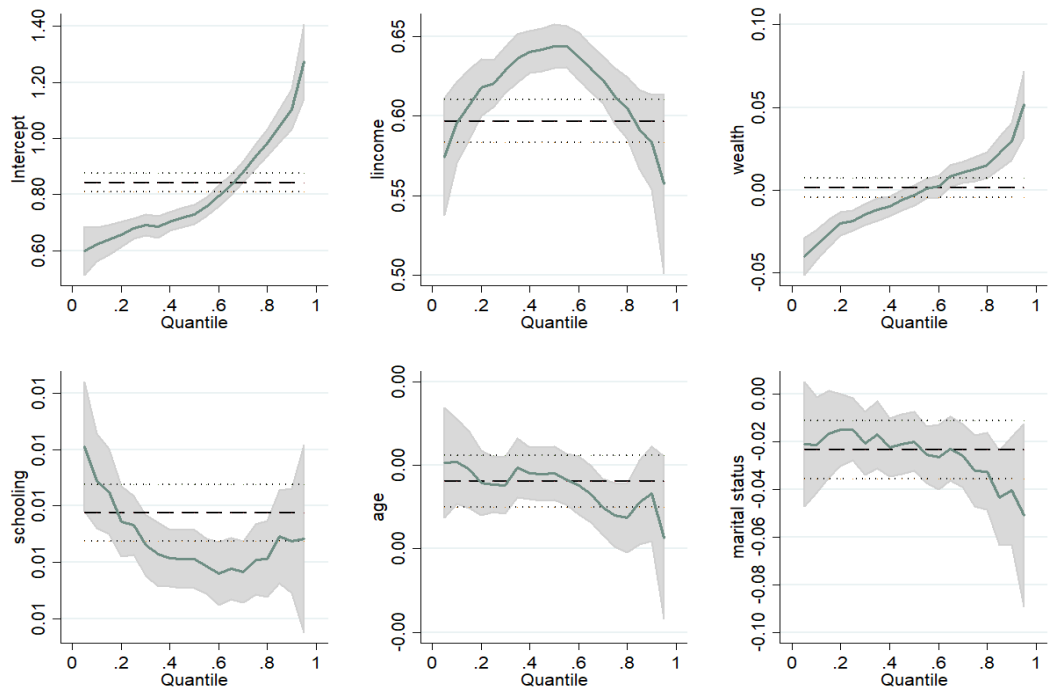

Table 4: Estimation Results of 2018

\begin{tabular}{|c|c|c|c|c|c|c|c|c|c|c|}
\hline & & LS & 0.2 & & 0.4 & & 0.6 & & 0. & \\
\hline & i & ii & i & ii & i & ii & i & ii & $\mathrm{i}$ & ii \\
\hline lincome & $.69^{* * *}$ & $.69^{\star * *}$ & $.69^{\star * *}$ & $.71^{\star * *}$ & $.71^{\star * \star}$ & $.72^{\star * *}$ & $.71^{* * *}$ & $.71^{\star * *}$ & $.72^{\star * *}$ & $.71^{\star * *}$ \\
\hline & $(66)$. & $(57.6)$ & $(66.5)$ & $(63.5)$ & $(75.2)$ & $(72.9)$ & $(78.3)$ & $(66.6)$ & $(54.7)$ & $(48.4)$ \\
\hline wealth & .002 & $.005^{\star \star}$ & -.006 & -.002 & $-.004^{*}$ & .0015 & .0022 & $.0044^{\star}$ & $.011^{\star * *}$ & $.013^{* * *}$ \\
\hline & $(1)$ & (3) & $* * \star(4)$ & $(0.89)$ & $(2.51)$ & $(0.90)$ & $(1.13)$ & $(2.19)$ & $(3.7)$ & $(4.5)$ \\
\hline saving & & $-.06^{* * *}$ & & $-.09^{* * *}$ & & $-.08^{* * *}$ & & $-.06^{* * *}$ & & $-.05^{* * *}$ \\
\hline & & (13) & & $(15.9)$ & & $(16.4)$ & & $(11.4)$ & & $(6.63)$ \\
\hline credit card & & $.053^{* * *}$ & & $.047^{* * *}$ & & $.048^{* * *}$ & & $.044^{* * *}$ & & $.055^{* * *}$ \\
\hline & & $(11.7)$ & & $(8.4)$ & & $(10.4)$ & & $(8.78)$ & & $(7.98)$ \\
\hline online & & $.05^{\star \star \star}$ & & $.037^{\star * *}$ & & $.038^{\star * *}$ & & $.049^{* * *}$ & & $.056^{* * *}$ \\
\hline shop. & & $(6.82)$ & & $(4.49)$ & & $(4.57)$ & & $(5.60)$ & & $(5.6)$ \\
\hline tobacco & & $.011^{\star *}$ & & $.012^{*}$ & & $.011^{\star *}$ & & $.013^{\star *}$ & & .0005 \\
\hline & & $(2.71)$ & & $(2.53)$ & & (2.69) & & $(2.83)$ & & $(0.07)$ \\
\hline alcohol & & $.027^{\star *}$ & & $.036^{*}$ & & $.021^{\star *}$ & & .016 & & .006 \\
\hline & & $(3.04)$ & & $(2.56)$ & & $(2.82)$ & & $(1.75)$ & & $(0.37)$ \\
\hline schooling & .005 & $.004^{* * *}$ & $.005^{\star * *}$ & $.004^{\star * *}$ & $.004^{* * *}$ & $.003^{* * *}$ & $.004^{* * *}$ & $.0036^{* * *}$ & $.005^{\star * *}$ & $.003^{* * *}$ \\
\hline & $\begin{array}{l}* * * \\
(9.7) \\
\end{array}$ & $(7.29)$ & $(8.29)$ & $(6.51)$ & $(7.30)$ & $(5.61)$ & $(8.08)$ & $(6.40)$ & & $(4.20)$ \\
\hline age & -.001 & -.001 & $-.0005^{\star *}$ & -.0003 & $-.0005^{* *}$ & $-.0004^{* *}$ & $-.001^{* * *}$ & $-.001^{\star * *}$ & $-.002^{* * *}$ & $-.002^{* * *}$ \\
\hline & $\begin{array}{l}* * * \\
(6.5) \\
\end{array}$ & $\begin{array}{r}* * * \\
(4.57) \\
\end{array}$ & $(2.61)$ & $(1.67)$ & $(2.85)$ & $(2.66)$ & $(6.38)$ & $(3.62)$ & (7.18) & (5.88) \\
\hline
\end{tabular}




\begin{tabular}{|l|cccccccccc|}
\hline marital & -.019 & -0.02 & -0.01 & -0.015 & -0.009 & $-0.02^{* * *}$ & $-.027^{* * *}$ & $-.029^{* * *}$ & $-.029^{* * *}$ & $-.033^{* * *}$ \\
status & $* * *$ & $* * *$ & $(1.44)$ & ${ }^{*}(2.1)$ & $(1.50)$ & $(4.24)$ & $(4.56)$ & $(4.80)$ & $(3.66)$ & $(4.03)$ \\
& $(3.3)$ & $(4.2)$ & & & & & & & & \\
\hline constant & $.99^{* * *}$ & $.98^{* * *}$ & $.84^{* * *}$ & $.76^{* * *}$ & $.87^{* * *}$ & $.81^{* * *}$ & $.97^{* * *}$ & $.95^{* * *}$ & $1.08^{* * *}$ & $1.09^{* * *}$ \\
& $(30)$ & $(26.7)$ & $(25.7)$ & $(21.9)$ & $(28.8)$ & $(26.1)$ & $(33.0)$ & $(28.4)$ & $(25.4)$ & $(23.6)$ \\
\hline $\mathbf{R}^{2}$ & 0.56 & 0.582 & 0.354 & 0.382 & 0.352 & 0.375 & 0.352 & 0.366 & 0.343 & 0.353 \\
\hline
\end{tabular}

Note: $t$ statistics in absolute value are in parentheses. ${ }^{*} \mathrm{p}<0.05,{ }^{* *} \mathrm{p}<0.01,{ }^{* * *} \mathrm{p}<0.001$

Saving has a significantly negative coefficient for all quantiles, yet this impact declines as quantiles rise. In line with our inference from the previous results, savings of the lowest quantiles are associated with a lower level of consumption more than that of upper quantiles. The positive and significant signs of credit card and online shopping - even after controlling for income - suggest that credit card usage and online shopping lead people to spend more. A one-year increase in education of the household head corresponds to an approximately 0.4 per cent increase in consumption expenditures. Age has a negative relation with consumption for all quantiles. The older the household head, the lower consumption expenditure. Marital status has a significant and negative connection with consumption expenditures implying that married couples spend less, especially within the higher quantiles. Tobacco and alcohol, after controlling for income, generally have significant and positive coefficients. It is not very surprising that households that use tobacco and alcohol have more consumption expenditure considering that these products are already consumption goods. Nonetheless, their costs are probably too low to be significant for the higher quantiles.

Graph 2 and Graph 3 indicate the confidence intervals of OLS and quantile regression. Horizontaldashed lines refer to confidence intervals of OLS estimation, whereas others show those of quantile regression. Confidence intervals of most of the variables based on quantile regression do not coincide with those of OLS. This finding again supports the significance of the quantile regression.

Graph 2: Confidence Intervals of OLS against Quantile Regression (2018-i)
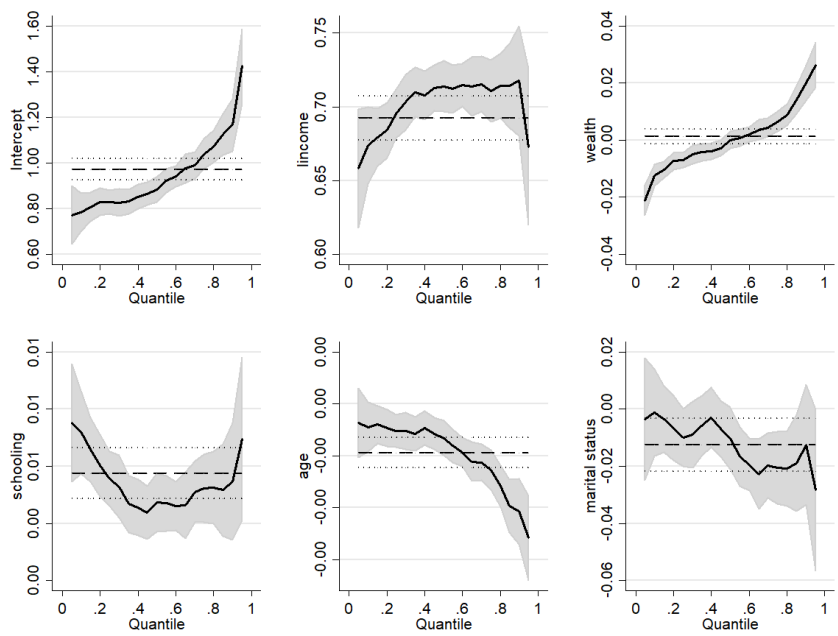
Graph 3: Confidence Intervals of OLS against Quantile Regression (2018-ii)
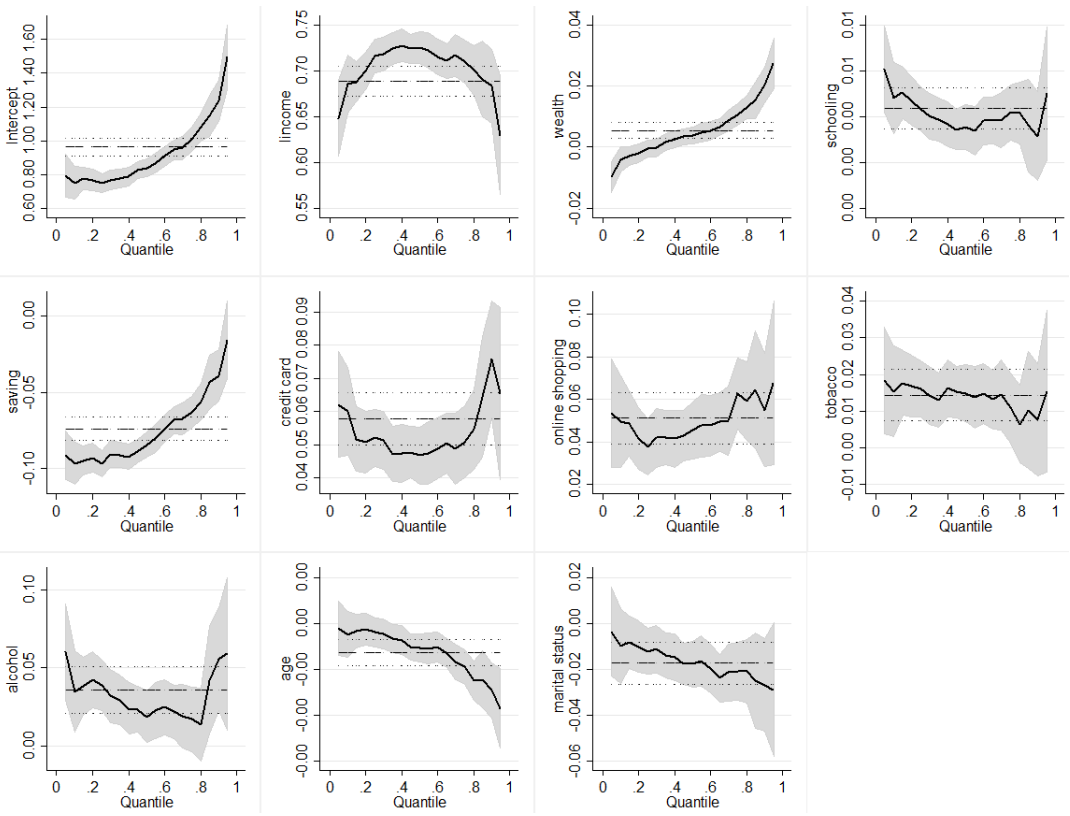

\section{Conclusion}

This study examines household consumption expenditures in Turkey for 2002 and 2018 by using Household Budget Surveys of TurkStat. Implementation of the quantile regression model has enabled us to capture some connections better than that of OLS. In general, disposable income is found to be a very important factor in explaining consumption expenditures confirming the conventional theories of consumption. The connection between income and consumption in 2018 is found stronger than that in 2002. This finding tells us that consumers tend to spend more of their incremental income in 2018 when compared to 2002. In other words, a rise in the marginal propensity to consume is observed for this period. The underlying reason for this rise might be related to increasing borrowing opportunities compared to 2002. For instance, the contingency saving of individuals against a financial emergency might have declined thanks to the development of the financial system in the Turkish economy.

Increases in the number of real-estate holding seem to be disassociated with the reduction of consumption (or rise in savings) for the highest quantiles in 2018. In other words, the attempt for wealth accumulation has little to do with economizing on consumption as there is an already existing saving that provides real estate holding for the well-off. Although households with more educated household-heads consume more in all estimations, this relation is relatively stronger in 2002. Moreover, although quantile coefficients of schooling are almost identical across quantiles in 2018 (an additional year of schooling raises consumption expenditure by around 0.4), they differ across quantiles in 2002 (an additional year of schooling increases the consumption expenditures of 
the lowest quantile by 1.3 per cent, and that of the highest quantile by 0.9 per cent). Households with married household heads have a lower level of consumption expenditure probably due to fixed costs of running a household. Though age is positively associated with consumption in 2002, its coefficient appears to be negative for 2018 showing an adverse relationship for the latter period. In other words, households with younger household heads seem to spend relatively higher in 2018. Considering the economic growth trends in the Turkish economy, this finding rather supports the life cycle theory which suggests that in a rapidly growing economy, lifetime resources of the younger generation are greater compared to that of the old in a slower-growing economy. In other words, households with younger heads spent more than those with older heads in 2018 during the times of high economic growth, contrary to the relationship for 2002 when The Turkish economy was staggering with the severe conditions of the crisis in the previous year.

This paper contributes to the literature by providing a comparison between household consumption expenditures in 2002 and those in 2018. Most studies on consumption are based on a household survey of a specific year and thus they fail to accomplish a dynamic analysis. Another contribution of this present study is to explore the links between consumption expenditures and some recently developed factors (i.e., credit card usage and online shopping) at the micro-level. From a utilitarian perspective (more is better), credit cards and online shopping are found as useful tools since they augment utility by consumption. On the contrary, from a minimalistic perspective, credit cards and online shopping might be interpreted as unfavourable factors that elicit excessive consumption higher than needs.

To sum up, assuming that utility is an increasing function of consumption (monotonic preferences), a higher level of household income, having a more educated household head, usage of credit-card and e-commerce are associated with a higher level of utility of households. On the other hand, although consumption increases utility and stimulates economic activity, excessive consumption may cause a saving gap which might threaten macroeconomic stability and cause serious fragilities in the long run. The recent decrease in the number of credit card instalments in hire-purchases can be regarded as an appropriate measure for curbing the excessive consumption pattern in Turkey. It is known that individuals consume exceeding their earnings, offered by the borrowing opportunities, causing negative savings. In the long run, these negative savings or accumulated debt may lead consumption to decrease, thereby affect the economy adversely. Transferring resources from excessive consumption back to savings would provide the financial means of productive investments and thus the facilitation of economic growth. Besides, there is a need for income redistribution by restructuring tax policies and thence the well-being of the less privileged may be raised. This would also provide the rise of social utility.

\section{References}

AKBAY, C., Boz, İ. (2007). Household Food Consumption in Turkey, European Review of Agricultural Economics, 34(2): 209-231.

ALBAYRAK, Ö. (2020). Household Consumption, Household Indebtedness, and Inequality in Turkey: A Microeconometric Analysis, Levy Economics Institute Working Paper, No: 954.

CERİTOĞLU, E. (2013). Household Expectations and Household Consumption Expenditures: The Case of Turkey, Central Bank of the Republic of Turkey Working Paper, No: 13/10. 
ÇAĞLAYAN, E., Astar, M. (2012). A Microeconometric Analysis of Household Consumption Expenditure Determinants for Both Rural and Urban Areas in Turkey, American International Journal of Contemporary Research, 2(2): 27-34.

DEATON, A. (1992). Understanding Consumption, Clarendon Press, Oxford.

DEMİREZEN, Ö. (2015). Türkiyede Kredilerin Özel Tüketim Harcamalarına Etkisi, T. C. Kalkınma Bakanlığı Uzmanlık Tezi.

DUESENBERRY, J. S. (1949). Income, Saving and the Theory of Consumer Behaviour, Cambridge: Harvard University Press.

FRIEDMAN, M. (1957). A Theory of the Consumption Function, Princeton, NJ: Princeton University Press.

HALL, R. (1978). Stochastic Implications of the Life Cycle-Permanent Income Hypothesis: Theory and Evidence, Journal of Political Economy, 86(6): 971-987.

JOHN, O. O., Nduka E. C. (2009). Quantile Regression Analysis as a Robust Alternative to Ordinary Least Squares, Scientia Africana, 8(2): 61-65.

KEYNES, J. M. (1936). The General Theory of Employment, Interest and Money, London: Macmillan.

KOENKER, R., Basset, G.W. (1978). Regression Quantile, Econometrica, 46(1): 33-50.

KOH, W. C., Köse, M. A., Nagle, P. S., Ohnsorge, F. L., Sugawara, N. (2020). Debt and Financial Crises, World Bank Policy Research Working Paper, 9116.

LEWIS, J. (2014). Income, Expenditure and Personal Wellbeing, 2011/12, UK Office for National Statistics.

LUO, X., Wang, Y., Zhang, X. (2019). E-Commerce Development and Household Consumption Growth in China, World Bank Policy Research Working Paper, No 8810.

MignounA, D. B., Abdoulaye, T., Alena, A., Manyong, V. M., Dontsop, P. N., Ainembabazi, J, H., Asiedu, R. (2015). A Microeconometric Analysis of Household Consumption Expenditure Determinants in Yamgrowing Areas of Nigeria and Ghana, Tropicultura, 33(3): 226-237.

MILES, D. (1997). A Household Level Study of the Determinants of Incomes and Consumption, The Economic Journal, 107: 1-25.

MODIGLIANI, F., Brumberg, R. (1954). Utility Analysis and The Consumption Function: An Interpretation of Cross-Section Data, In the Collective Papers of Franco Modigliani, Volume, Cambridge, MA and London: MIT Press.

OECD (2013). OECD Framework for Statistics on the Distribution of Household Income, Consumption and Wealth, OECD Publishing, https://read.oecd-ilibrary.org/economics/framework-for-statistics-on-thedistribution-of-household-income-consumption-and-wealth_978.926.4194830-en\#page1, (Accessed on 15.12.2020)

ÖNDER, K. (2018). The Effect of Credit Card Usage on Consumer Behavior, International Journal of Eurasia Social Sciences, 9(32): 1099-1120.

SCOTT, R. H. (2007). Credit Card Use and Abuse: A Veblenian Analysis, Journal of Economic Issues, 41(2): 567-574.

STIGLITZ, J., Sen, A., Fitoussi, J. P. (2009). Report of the Commission on the Measurement of Economic Performance and Social Progress, https://ec.europa.eu/eurostat/documents/8131721/8131772/StiglitzSen-Fitoussi-Commission-report.pdf, (Accessed on 10.06.2021)

TAPSIN, G., Hepsag, A. (2014). An Analysis of Household Consumption Expenditures in EA-18, European Scientific Journal, 10(16): 1-12.

TURKISH STATISTICAL INSTITUTE (2018). Household Budget Statistics Micro Data Set, https://www.tuik. gov.tr/media/microdata/pdf/hanehalki-butce_YeiTwew.pdf, (Accessed on 10.06.2021) 
TURKISH STATISTICAL INSTITUTE (2020). Annual GDP 2019, Press Bulletin, https://data.tuik.gov.tr/ Bulten/Index?p=Annual-Gross-Domestic-Product-2019-33671, (Accessed on 07.06.2021)

TURKSTAT (2002). Household Budget Statistics Micro Data Set 2002.

TURKSTAT (2018). Household Budget Statistics Micro Data Set 2018.

VEBLEN, T. (1899). The Theory of the Leisure Class, Reprint, Delhi: Aakar Books, 2005.

VERTER, N., Osakwe, C. (2014). A Time Series Analysis of Macroeconomic Determinants of Household Spending in the Era of Cross-cultural Dynamics: Czech Republic as a Case Study, Procedia Economics and Finance, 12(2014): 733-742.

WANG, H., Sindelar, J., Bush, S. (2006). The Impact of Tobacco Expenditure on Household Consumption Patterns in Rural China, Social Science \& Medicine, 62(6): 1414-1426. 


\section{ANNEX}

Table A.1 Classification of Individual Consumption According to Purpose

\begin{tabular}{|l|l}
\hline $\mathbf{0 1}$ & Food and non-alcoholic beverages \\
$\mathbf{0 2}$ & Alcoholic beverages, tobacco and narcotics \\
$\mathbf{0 3}$ & Clothing and footwear \\
$\mathbf{0 4}$ & Housing, water, electricity, gas and other fuels \\
$\mathbf{0 5}$ & Furnishing household equipment and routine household maintenance \\
$\mathbf{0 6}$ & Health \\
$\mathbf{0 7}$ & Transport \\
$\mathbf{0 8}$ & Communication \\
$\mathbf{0 9}$ & Recreation and culture \\
$\mathbf{1 0}$ & Education \\
$\mathbf{1 1}$ & Restaurants and hotels \\
$\mathbf{1 2}$ & Miscellaneous goods and services \\
\hline
\end{tabular}

Table A.2 Summary Statistics $(2002)^{40}$

\begin{tabular}{|c|c|c|c|c|c|}
\hline Variable & Number of households & Mean & Std. Dev. & Min. & Max. \\
\hline consumption & 9551 & 280 & 312.6 & 6.03 & 8622 \\
\hline income & 9551 & 328 & 490 & 2.56 & 22219 \\
\hline wealth & 9551 & .375 & .67 & 0 & 5 \\
\hline schooling & 9551 & 6.20 & 4.66 & 0 & 18 \\
\hline age & 9551 & 45.7 & 13.54 & 15 & 98 \\
\hline gender & 9551 & .90 & .30 & 0 & 1 \\
\hline marital status & 9551 & .88 & .32 & 0 & 1 \\
\hline weight & 9551 & 1721 & 1973 & 96 & 15421 \\
\hline
\end{tabular}

Table A.3 Summary Statistics (2018)

\begin{tabular}{|lccccc|}
\hline Variable & Number of households & Mean & Std. Dev. & Min. & Max. \\
\hline consumption & 11818 & 2171 & 1939 & 109 & 35526 \\
\hline income & 11818 & 2448 & 2408 & 87 & 69521 \\
\hline wealth & 11818 & 1.40 & 1.49 & 0 & 24 \\
\hline saving & 11818 & .38 & .48 & 0 & 1 \\
\hline schooling & 11818 & 7.27 & 5.03 & 0 & 22 \\
\hline age & 11818 & 50.6 & 14.5 & 17 & 97 \\
\hline gender & 11818 & .85 & .36 & 0 & 1 \\
\hline marital status & 11818 & .82 & .39 & 0 & 1 \\
\hline credit card & 11818 & .50 & .50 & 0 & 1 \\
\hline online shopping & 11818 & .10 & .30 & 0 & 1 \\
\hline tobacco & 11818 & .52 & .50 & 0 & 1 \\
\hline alcohol & 11818 & .06 & .23 & 0 & 6082 \\
\hline weight & 11818 & 1995 & 1229 & 375 & \\
\hline
\end{tabular}

40 Master and $\mathrm{PhD}$ graduates are not separated in the survey. Whether a household head has Master's or PhD degree is unknown, so that schooling years of both groups have been assumed as 18 years. 
Table A.4 Pairwise Correlations (2002)

\begin{tabular}{|lccccccc|}
\hline & lcons & lincome & wealth & schooling & gender & age & maritalst. \\
\hline lcons & 1.00 & & & & & & \\
\hline lincome & $0.755^{*}$ & 1.00 & & & & & \\
\hline wealth & $0.085^{*}$ & $0.121^{*}$ & 1.00 & & & & \\
\hline schooling & $0.451^{*}$ & $0.457^{*}$ & $-0.037^{*}$ & 1.00 & & & \\
\hline gender & -0.016 & -0.008 & $0.048^{*}$ & $0.171^{*}$ & 1.00 & & \\
\hline age & $0.036^{*}$ & $0.058^{*}$ & $0.177^{*}$ & $-0.307^{*}$ & $-0.18^{*}$ & 1.00 & \\
\hline maritalst. & $0.0443^{*}$ & $-0.048^{*}$ & $0.035^{*}$ & $0.141^{*}$ & $0.779^{*}$ & $-0.218^{*}$ & 1.00 \\
\hline
\end{tabular}

Table A.5 Pairwise Correlations (2018)

\begin{tabular}{|c|c|c|c|c|c|c|c|c|c|c|c|c|}
\hline & lcons & lincome & wealth & saving & $\begin{array}{l}\text { credit } \\
\text { crd }\end{array}$ & $\begin{array}{l}\text { online } \\
\text { shop }\end{array}$ & tobacco & alcohol & school & gender & age & $\begin{array}{l}\text { marita } \\
\text { stat. }\end{array}$ \\
\hline lcons & 1.00 & & & & & & & & & & & \\
\hline lincome & $.73^{\star}$ & 1.00 & & & & & & & & & & \\
\hline wealth & $.14^{*}$ & $.24^{*}$ & 1.00 & & & & & & & & & \\
\hline saving & $.21^{*}$ & $.42^{*}$ & $.18^{*}$ & 1.00 & & & & & & & & \\
\hline creditc. & $.41^{\star}$ & $.41^{*}$ & -.008 & $.17^{\star}$ & 1.00 & & & & & & & \\
\hline onlines. & $.3^{*}$ & $.31^{*}$ & -.01 & $.16^{*}$ & $.27^{*}$ & 1.00 & & & & & & \\
\hline tobacco & $.03^{*}$ & $-.03^{*}$ & $-.13^{*}$ & $-.1^{*}$ & $.07^{\star}$ & .001 & 1.00 & & & & & \\
\hline alcohol & $.18^{\star}$ & $.18^{*}$ & -.003 & $.03^{*}$ & $.09^{*}$ & $.11^{\star}$ & $.13^{*}$ & 1.00 & & & & \\
\hline school & $.43^{*}$ & $.46^{*}$ & $-.08^{*}$ & $.22^{\star}$ & $.41^{\star}$ & $.33^{*}$ & .002 & $.12^{\star}$ & 1.00 & & & \\
\hline gender & .01 & .009 & $.09^{*}$ & $.03^{*}$ & $.13^{*}$ & .014 & $.12^{*}$ & $.04^{*}$ & $.15^{\star}$ & 1.00 & & \\
\hline age & $-.1^{\star}$ & $.02^{*}$ & $.34^{*}$ & -.02 & $-.2^{*}$ & $-.2^{*}$ & $-.2^{*}$ & $-.04^{\star}$ & $-.4^{*}$ & $-.2^{*}$ & 1.00 & \\
\hline maritlst. & $-.03^{*}$ & $-.05^{\star}$ & $.09^{*}$ & $.02^{*}$ & $.12^{*}$ & -.01 & $.10^{*}$ & $-.03^{*}$ & $.10^{*}$ & $.70^{*}$ & $-.2^{*}$ & 1.00 \\
\hline
\end{tabular}

